\title{
Enquete: Danske hajer
}

Jeg tror, det var et år efter, at jeg var flyttet til Danmark, at jeg så et indslag fra Kattegatcentret i Grenå i de lokale nyheder. Reporteren (R) stod ved siden af et stort bassin og snakkede med en ansat (A) fra Centret om nogle af de nye attraktioner, som bes $\varnothing$ gende kunne forvente at stifte bekendtskab med i det nye år. Interviewet forløb nogenlunde på denne måde:

R: „Er der nogle nye attraktioner i år?““

A: „Ja, blandt andet har vi fået disse hajer, som svømmer her i tanken.“

R (kigger på fiskene): „Nå, men disse hajer er ret små og brune og ikke så spændende. I har jo allerede sådan nogle flotte, store farligt-udseende hajer her i centret, som er langt mere interessante. Hvorfor skal I så have sådan nogle kedelige nogle også?"

A: „Jamen, de her er danske hajer.“

R: „Hvad er ellers nyt i år?...“

Konversationen fortsatte i et par minutter om andre ændringer og tilføjelser til Centrets attraktioner, og hajerne blev ikke nævnt igen.

Der findes et udtryk på engelsk: „It takes one to know one“, som er relevant i genkendelsen af nationale fællesheder: Danskere genkender danskere lettere end hollændere gør - eller sådan er antagelsen. Dette bygger på en forestilling om, at man ,rent faktisk“ har noget til fælles, når man er dansker, selvom der ikke nødvendigvis er enighed om eller klarhed over, hvad dette ,noget“" præcis er.

Det er min erfaring, at det er typisk dansk at spørge udlændinge om, hvad de synes er typisk dansk. Allerede når spørgsmålet stilles, kan forventningens glæde spores i spørgerens tone og ofte ses i ansigtsudtrykket: Der vil følge en bekræftelse af en eller anden „,klassisk“ stereotyp forestilling om noget, der blandt danskere opfattes som typisk dansk. Man kender på forhånd repertoiret af mulige svar, og glæden ved udlændingenes genkendelse er netop udtryk for anerkendelsen af dette eller hine nationale særpræg. For den adspurgte udenlandske statsborger ligger der også en vis udfordring i spørgsmålet: Har man allerede forstået, hvad der er typisk dansk?

Den banale nationalismes spilleregler i Danmark kræver - det lærer man hurtigt - at man nævner et eller andet positivt træk, som danskere selv gerne (og ofte) minder både udlændinge og hinanden om, er typisk dansk. Altså for eksempel at danskere er uhierarkiske og hyggelige mennesker. Det er ikke meningen, at den adspurgte fremhæver, at danskere er autoritetstro, eller - måske det værste overhovedet - nationalistiske. Og det er heller ikke meningen, at man skal gå ind og analysere stereotypernes manglende overensstemmelse med de danskheder, man møder på gaden, i danskernes huse og institutionerne. Eller at man påpeger, at nogle natio- 
nale symboler måske ikke er så eksklusivt danske, som danske nationale forestillinger antyder.

$\mathrm{Nu}$ er der selvfølgelig ikke enighed i Danmarks befolkning om, hvad danskheden nu præcis er. Til gengæld synes der ikke at være grænser for, hvor meget man er villig til at diskutere danskhedens indhold. Og det er nok denne forestilling om danskhedens realitet og vigtighed, som skal ses som „typisk dansk“. Det er der, forskellen kan findes til for eksempel den tyske debat om „Leitkultur“, hvor der stilles spørgsmålstegn ved hele forestillingen om, at man skulle have en fælles ,,identitet“. I Danmark synes der nærmest at være konsensus om, at danskheden findes, og at det er en god ting, og at den skal bevares. Med andre ord: Det særlige ved danske forestillinger om danskheden er netop at der ikke stilles spørgsmål ved dens eksistens; den tages for givet.

Det er denne „tagen-for-givethed“, som den engelske socialpsykolog Michael Billig belyser i sin analyse af det, han kalder den banale nationalisme. Dens banalitet bevirker, at hverdagens små signaler og påmindelser om nationen ikke længere genkendes som nationalistiske. Mange danskere benægter, at danskere skulle være nationalistiske, selvom det nationale gennemsyrer det offentlige rum og diskurs. Det danske flag er allerstedsnærværende, og enhver anledning benyttes til at synge ,traditionelle“ sange fra 1800-tallet, hvoraf mange på perfekt vis eksemplificerer det romantiske, nationalistiske projekt. Men disse eksempler betragtes ikke som nationalistiske. I nogle tilfælde, for eksempel brugen af flaget, findes nationale standardformer for denne benægtelse af nationalistiske betydninger: Det signalerer bare fest og glæde... En nærmere analyse af „Blut und Boden“-romantikken i mange sange er heller ikke noget, man synes at bruge megen tid på: De er blot sange, og man er bare glad for sit land. Denne ureflekterede brug af nationalistiske symboler og retorik, sammen med andre elementer af den banale nationalisme, som for eksempel vilje i befolkningen til at udtale sig på vegne af nationen (,,vi“, ,,vi danskere“ eller ,danskere“) og til at betegne ting, holdninger, handlinger som ,udansk“, er med til at sikre den naturalisering af det nationalistiske verdenssyn, mens ideologien sletter sporene af sin egen umulighed.

Selvfølgeligheden af danskheden kommer klart til udtryk i indslaget om Kattegatcentrets danske hajer. Det er ikke kun eller især den ansattes betegnelse af hajerne som danske, som er interessant - selvom det ville være sjovt at udspørge ham lidt om, hvad han mener, der gør dem til danske - men reporterens totale, selvfølgelige accept af forklaringen. I en verden, hvor stort set alt ses gennem nationalismens linse, er der selvfølgelig danske landskaber, danske værdier, dansk kultur og - logisk nok - danske køer, svin og hajer. Men hvad betyder det at sige, at en haj er dansk? Og hvad finder man ved nærmere betragtning? 